$\begin{array}{ll} & \text { Etnográfica } \\ \text { etnográfica } & \text { Revista do Centro em Rede de Investigação em }\end{array}$ Antropologia

vol. $22(2) \mid 2018$

Vol. $22(2)$

\title{
Reflections concerning ethnographic ethical decisions and neo-liberal monitoring
}

Monitorização neoliberal e decisões éticas na etnografia: algumas reflexões

\section{Tiago Neves, Chris Holligan and Ross Deuchar}

\section{(2) OpenEdition}

\section{Journals}

Electronic version

URL: https://journals.openedition.org/etnografica/5270

DOI: 10.4000/etnografica.5270

ISSN: 2182-2891

\section{Publisher}

Centro em Rede de Investigação em Antropologia

\section{Printed version}

Date of publication: 1 June 2018

Number of pages: 241-258

ISSN: 0873-6561

\section{Electronic reference}

Tiago Neves, Chris Holligan and Ross Deuchar, "Reflections concerning ethnographic ethical decisions and neo-liberal monitoring", Etnográfica [Online], vol. 22 (2) | 2018, Online since 07 July 2018, connection on 20 January 2022. URL: http://journals.openedition.org/etnografica/5270 ; DOI: https:// doi.org/10.4000/etnografica.5270

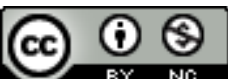

Etnográfica is licensed under a Creative Commons Attribution-NonCommercial 4.0 International License. 


\section{Reflections concerning ethnographic ethical decisions and neo-liberal monitoring}

\section{Tiago Neves, Chris Holligan and Ross Deuchar}

Hypothetical, speculative ethical concerns are no match for real situations. As such, this paper argues that there is an unsurpassable gap between planned, prescriptive ethics and real-time, relational, ethnographic decision making. The enforcement of procedural ethics may actually prevent the development of ethnographic work. Also, we critically assess procedural ethics as being not really about ethics, but rather about the risk management embedded in contemporary academia. We organize ethical issues in three political vectors (the ethnographer him/herself, the relationships with the people in the field, and the ethnographic texts), and then offer suggestions for a humanistic research ethics that involves reclaiming the researchers' ethical power, enlarging the notion of what is ethical, and accepting that there is a darker side to ethnography. The account offered here is based on the ethnographic experience of Portuguese and Scotland-based researchers.

KEYWORDS: ethnography, critical ethnography, ethics, IRB and academic freedoms.

Monitorização neoliberal e decisões éticas na etnografia: algumas reflexões $\mathrm{Na}$ ética, preocupações hipotéticas e especulativas não correspondem a situações reais. Existe um hiato insuperável entre uma ética processual e prescritiva e os processos de tomada de decisão etnográficos, relacionais e necessariamente em tempo real. A aplicação de uma ética processual pode chegar a impedir o desenvolvimento de trabalho etnográfico. Uma avaliação crítica da ética processual revela que o seu objeto não é realmente a ética, mas sim a gestão de riscos tal como tem sido incorporada na academia contemporânea. Organizamos as questões éticas em três vetores políticos (o/a etnógrafo/a, as relações com as pessoas no terreno e os textos etnográficos) e avançamos propostas para uma ética humanista de investigação, que passa pela recuperação do poder ético dos pesquisadores, por ampliar a noção do que é ético e por aceitar que a etnografia tem um lado mais sombrio. O relato aqui apresentado baseia-se na experiência etnográfica de investigadores portugueses e escoceses.

PALAVRAS-CHAVE: etnografia, etnografia crítica, ética, comités de ética e liberdades académicas.

NEVES, Tiago (tiago@fpce.up.pt) - Centro de Investigação e Intervenção Educativas (CIIE), Faculdade de Psicologia e de Ciências da Educação, Universidade do Porto, Portugal.

HOLLIGAN, Chris (chris.holligan@uws.ac.uk) - School of Education, University of the West of Scotland, Scotland.

DEUCHAR, Ross (ross.deuchar@uws.ac.uk) - School of Education, University of the West of Scotland, Scotland. 
Our paper is inspired by the authors' ethnographic experiences in the field and "on the veranda" which, since the mid-nineties, have focused on sensitive issues and the hidden politics of marginalized people at the base of the capitalist class pyramid - for example, working-class drug users, policing communities, the underground night-time economy, state detention and incarceration of young people, and youth support community contexts supporting disadvantaged areas. Portugal and Scotland are the background national scenes where we have sought to bring out the voices of those experiencing a turbulent and dangerous urban life, and where for many years we have each been involved in actively conducting ethnographic fieldwork while working actively as full-time academics. We began to feel an intensification in terms of how we as researchers were being subjected to the politics of institutional surveillance, hence our desire to share the ideas in this paper. Others may also have encountered the policing of their ideas and research aspirations; we hope our discursive paper generalizes through psychological resonance, and shared politics.

Hypothetical, speculative procedural ethical concerns are no match for the phenomenology of real world situations packed with existential dilemmas (Weppner 1977; Burgess 1997). At best, abstracted ethics formulated from the comfort of a proverbial armchair are a sort of anxiety reducing practice for giving the self the belief that dealing with the unpredictability of ethnographic life in the field is within the scope of abstracted reasoning nourished by immersion in appropriate canonical texts. At worst, the relevant ethical concerns are resistant to a priori resolution; the procedural logic characterizing institutional audit-culture practices where group-thinking is difficult to evade offers false hope to the researcher and misleads by conjuring the ethical landscape as being easily amenable to conclusive and widespread consensus: instead the truth is this deluded mind-set offers nothing more than a tentative rationalization of ethical dilemmas that cannot be solved by reason and extensive scientific citation. The customary reliance upon written ethical approval based upon appraisal of written documents submitted is also obnoxious to us on moral grounds because it obscures attention from the virtues of the researcher upon whose own ethical integrity any research revolves.

In other words, the actual relevance, meaning and difficulty of ethical issues can only be fully appreciated in the face of concrete, context-bound situations which challenge the researcher's own auto-biographical wisdom, often leading her/him to assent to pragmatic as opposed to ethical resolutions. Indeed, conformity to institutional research ethics board prescriptions may undermine the quality and originality afforded by autonomous researchers (Deuchar 2016; Locke, Ovando and Montecinos 2016). The historical context of higher education indicates immense commercialization tendencies, profound 
audits defining research worth and evermore dependence on gaining financial resources outside of the state from capitalist enterprises. Capitalism contains a model of the virtuous person and models of research impact or relevance. It is foolish to overlook the ideology it advocates given the intensification of capitalist logics into the nature and operation of the university system in the $21^{\text {st }}$ century. As critical criminologists, we are sympathetic to the vision of Jock Young expressed in The Criminological Imagination, where he makes us aware of how criminal justice is biased towards serving vested interests of the existing social class hierarchy.

The radical nature of the ethical relativism associated with Jock Young's vision has serious implications for the focus of our discursive paper. In brief, if as researchers our ethical stance involves moral empathy towards the marginalized groups we work with, this potentially puts us at loggerheads with the universal ethical orientation inherent in institutional ethics approval processes. Moreover, being consistent with our subversive intellectual sensitivity in relation to our desire to critique capitalism and its legitimation through criminal "justice" means we are pushed into even greater opposition with, and therefore exclusion by, traditional approaches to the approval of the ethics of any research inquiry by formally approved ethical review bodies. In terms of our argument, the decisions they enforce upon researchers, especially in the light of the contemporary nature of higher education, means that the oppression we seek to highlight is reinforced as one is legally obligated to respect a capitalist order culpable for producing the injustices that Jock Young eloquently exposes. It should be clear that we take a position of ethical relativism in terms of the conduct of research relations in the field and knowledge production.

Yet, institutionally-based "anticipatory regulatory regimes," the home of procedural ethics and legacy of biomedical heritage stemming from the Nuremberg Code hegemony, we argue, serve the interests of capitalist logic (Murphy and Dingwall 2007; Hammersley and Traianou 2014; Neves and Malafaia 2016). The hegemonic status of their power to impose conformity over the autonomy of researchers ex cathedra is widely acknowledged, although some believe meaningful compromise is possible (Connolly 2007). The cynic would argue throughout higher education this obsessive concern with academic research ethics does not reflect a recently discovered fascination for the intrinsic merits of research and ethical justification and legitimating, instead it reflects an instrumentalist anxiety over potential and costly law suits leading to reputational damage, should research participants or others judge their rights to have been infringed (Berg, Huijbens and Larsen 2016). In this dystopian framing, regulatory research ethics is not really about ethics, but risk management. In this paper we address the strain put on ethnographic practices by the existence of a dialogic tension between those two different modes of research 
ethics "regulation". We then explore the supposed contribution of reflexivity to the production of unresolved contestations in the field.

\section{UNDERSTANDING OUR ETHNOGRAPHIC SENSIBILITY}

To begin with, we present our understanding of what ethnography is about. We believe this is important for the sake of clarity, as there has always been contestation within ethnography as a concept and material praxis (Atkinson, Coffey and Delamont 1999). Also, this is necessary for the sake of relevance to our questioning political project, as such variety inevitably provokes conflicting ethical concerns and provisional solutions. Finally, if we concur with Adler and Adler (1987) that epistemology and reflexivity are at the heart of ethnography, then surely a text on reflexivity in ethnography must celebrate and model critical reflexivity. This involves making the authors' own politics and intellectual affiliations transparent in order to "objectivate the subject of the objectification" (Bourdieu 2004: 86). It also means realizing that the ethical and moral dilemmas of ethnography, and particularly of the ethnographies of crime and deviance, "are not necessarily predicaments but essential building blocks of analysis of the research setting" (Diphoorn 2013: 202).

As we see it, then, ethnography has four core elements. First, the goal of ethnography: in the Greek etymology, "ethno" refers to cultural group and "graphein" to writing. Therefore, ethnography is an endeavour to write about, to describe, a given group or community with a focus on its cultural features. For some this is but a part of a wider project to advocacy and support mobilization. Geertz (1993) has influentially defined the research angle of this goal as "thick description", meaning that behaviour and context must be explained together so as to effectively make sense of the world in terms of local knowledge (Biersack 1989).

Second, such "thick description" requires a particular research method. That method is extensive participant observation where through embodiment researchers "translate" the culture examined through their own conceptual scheme: interpreting a different culture entails critical reflection on the assumptive basis of one's own. Through deep immersion in the field, inside knowledge is developed: that is, grasping the world vision of the Other, but necessarily also seeing one's own cultural baggage as similarly strange and contingent in the process (Hammersley and Atkinson 2007). In the 1920s, Malinowski (1984 [1922]) had already pointed out that inside knowledge is a central feature of ethnography, although his personal diaries demonstrated prejudices which contaminated his integrity of respect for other ways of being. Anthropologically developed knowledge emerges from the ability - and the tension - of being simultaneously in and out of the researched group, close and distant, participating but not being or becoming a full member (Adler, Adler 
and Rochford 1986; Castellano 2007; Hammersley and Atkinson 2007; Lewis and Russell 2011).

Unless the researcher has well-honed social skills, he/she is likely to be rejected, suffering the fate of some who return home banished and shamed. Only long, deep, respectful immersion in the field of communities studied enables ethnography to become "the art of getting answers without asking questions" (Costa 1986: 136). However, in today's highly-pressurised academic world, it is very difficult to hold onto a romanticized view of the need for prolonged immersion in the field. In reality, competing priorities and time constraints often mean that long-term reflection while in situ is minimized and "micro" ethnographies become the norm. Whatever the extent of the immersion, asking questions too early in fieldwork is a recipe for negative experience and ostracism. This seems particularly relevant for the ethnographies of crime and deviance where the politics of relativism are an inescapable part of the legal system's historical basis in a class hierarchy of power and the state's legal violence: asking questions is a trademark of a political brand reflecting an intrusive "curiosity" social control agencies inflict upon marginalized and powerless groups whose goal is more effective management and control. Michel Foucault's reflections on research ethics highlight how knowledge is produced through power relations rather than rationality (Hammersley and Traianou 2014). Despite appearing trivial, the two paragraphs above set political frontiers and discursive boundaries. Namely, they leave out the so-called auto-ethnographies (Brunt 1999), as well as research that relies heavily on more structured arrangements for data collection (focus groups, interviews, and so on) or on technical equipment (namely video and audio recorders). It needs to be said that the current cornering of ethnography by anticipatory regulatory regimes may have the perverse effect of contributing to promote such mitigated forms of ethnography and helping ensure the state's regulatory desires of the populace continues. More on that later.

Third, the ethnographer is fundamentally an embodied research instrument (Walsh 1998; Fernandes 2002). That position highlights the unavoidable contribution of the researcher's own ethics and politically connected stance towards the world. This is a consequence of the centrality of a typically solitary participant observation and deep immersion in fields historically at great distances from the homes of the researchers. The process of data collection relies upon becoming accepted by those one is trying to research. Also, it is the result of the ethnographer usually concentrating on him/her, as an individual, the process of data analysis which requires her/him to question their inherited cultural baggage. This focus on data collection and analysis is fundamental if one concurs with Anderstaay (2005) that the goal of ethnography is the production of knowledge (rather than, for example, the emancipation of the people one is researching). However, we do not see the ethnographer as a 
mechanistic kind of knowledge-production machine. Quite the contrary: the concentration of technical activities is necessarily accompanied by an emotional approximation to the field and the people in it (Neves 2008). Identities have to be flexible, caring and empathetic if the immersion is to work. Indeed, generating inside knowledge requires personal implication of the ethnographer, often leading to significant - sometimes difficult to integrate - amounts of resocialization in the field (Emerson, Fretz and Shaw 1995; Neves 2008). Some social anthropologists never return to their place of origin, having found solace in "going native".

Finally, we believe ethnographic texts as products of a research enterprise are the fourth core element of ethnography. This, of course, is a result of the descriptive goal of ethnography, as mentioned above. Texts, in the form of field notes, are the main recording device in ethnography, coupled increasingly with the affordances of visual technologies, cameras and videos. However, they are more than an "external hard drive" for the ethnographer: they are the main supplier of data for ethnographic analysis, and they are also the final product of ethnography whose characterizations are inevitably only partially valid as they cannot avoid presenting a static portrait of real people and places (Emerson, Fretz and Shaw 1995). Goal, method, main instrument, and recording and analytical device: the four core elements of ethnography as we understand them. Surely, they are presented separately not because they are independent, but for presentational clarity. Being reflexive is also being aware of the inevitability (and bias) of any rational reconstruction of the research process (Bourdieu 2004).

\section{ETHNOGRAPHIES OF DEVIANCE AND VIOLENCE}

Again, the reflexive nature of the ethnographic text commands that the authors' own ethical and political perspectives are clarified and stated. It is necessary to make the researcher's stance a topic in itself, to realize the context-bound nature of his/her knowledge (Lumsden 2012). Following on from what we said in the previous section, we see ethical issues in our conception of ethnography organized around three political vectors: the ethnographer him/herself, the relationships with the people in the field, and the ethnographic texts.

Since Max Weber at least, who was far from being a radical subjectivist and was writing well before the term "reflexivity" became part of sociology's modus vivendi, it is widely accepted that all social science unavoidably refers to and presupposes values (Weber 1949). So, with regard to the ethnographer him/herself, this means that the researcher cannot leave behind his/her gender, age, personal history, cultural characteristics, psychological traits, political and epistemological stances, all of which not only condition the choice of his/her research topics, methods and objectives, but are constitutive of underlying 
ontology and epistemology. Why do some researchers decide to study prostitution, violence, the addictions or madness? What for? What drives us, ethnographers of crime and deviance? Michel Foucault appeared to think marginalized groups depicted the operation of societal processes which are less easily surfaced through the study of mainstream: voyeurism (Roberts 1975; Bourgois 1996; Jenks and Neves 2000), romantic empathy with the underdogs (Irwin 2006), a will to change the world (Stein 2010), the desire to impress others with our courage and stories from dangerous worlds (Keith 1992), the production of knowledge, career opportunity and progression are examples of the human condition of a research community's engagement with the Other. Although a combination of these motives matters for some scholars, others may act more out of intellectual curiosity about the lives of others whose path they don't cross in their personal lives.

Collectively, as ethnographic researchers we recognize that we have been through each and every one of those, moving from a more romantic approach - which was also more voyeuristic - to a more instrumental one. If we seek to understand the values of others and how they socially construct the meanings defining who they are and the choices they make, we benefit from clarifying our own constructs as they help define these encounters with strangers. We need not only worry about the people in the field and the people who will read our work, but also about continuing to live with ourselves (Whyte 1993 [1943]), a theme resonant of the gap in the ethics approval process which neglects attention to the ethical values of the researcher as a person. Of all people, ethnographers should know the limits of an apparent context-free, disembodied bureaucratically constructed ethical code (Deuchar 2016). If not, how are we as critical researchers to suggest alternatives to administrative, aprioristic, impersonal, anticipatory regulatory regimes on whose employment and power to approve we depend?

In what refers to the relationships with the people in the field, there are a number of themes that have been consistently addressed in the ethnographic literature. It is striking that those ethical themes are simultaneously, more often than not, also central methodological issues connected with immersion through participant observation. This is because, given the specificity of the ethnographic approach, the method spills over from the relationship with the research process to the relationships both with the subjects in the field, their lives, histories, fears and achievements, and later with the highly educated scholarly readers that join this community (Neves 2008).

Informed consent (Tolich 2004; Murphy and Dingwall 2007), reciprocity (Whyte 1993 [1943]; Ferdinand et al. 2007), and the ethnographer's more overt or covert status (Adler, Adler and Rochford 1986; Van Deventer 2009) for instance, are commonly regarded as nuclear ethical issues. The interaction of these three elements necessarily involves a degree of what Erving Goffman 
describes as being a process of strategic impression management (Goffman 1969; Fine 1993; Hammersley and Atkinson 2007). Or, if we would like to frame this in less neutral terms, mild forms of manipulation, "subterfuge and/or obfuscation" (Allbutt and Masters 2010: 214), "deceit and exploitation" (Ferdinand et al. 2007: 533), "methodological grooming" (Bengry-Howell and Griffin 2012) or "ethnographic seduction" (Diphoorn 2013: 203) of research participants. All of these social dynamics are on-going, dynamic encounters; the processes are typically tacit and invisible to the players. Because they mimic "real life", because they are real life, they cannot be solved in anticipation by filling in administrative forms. It might be argued that the degree of manipulation and seduction varies as a function of the difficulty of gaining access to a given field. If true, this would mean that ethnographers of crime and deviance probably incur to a larger extent in such behaviours. One of us certainly felt that in his earlier studies on drug addiction, as he stretched his middle-upper class self to new postures and behaviours to ensure gaining access to a world different from his own. To manipulate others one needs also to manipulate oneself. Then one becomes more elastic, revising one's own notions of what is good, correct or appropriate, often to incorporate elements of the worldview of the apparently powerless. It appears, then, that there is no possibility of ethical purity in ethnography. A simple reality check tells us that life in general involves getting one's hands dirty. Why would - or rather, how could - ethnographic life be very different when its method seeks, by and large, to emulate the common life themes of others in scholarly fashion? Bronfenbrenner's statement that "the only safe way to avoid violating principles of professional ethics is to refrain from doing social research altogether" (Bronfenbrenner 1952, cited in Fine 1993: 267) fits like a glove to the conduct of ethnography as we construe its gaze and research demands.

Finally, a brief comment on ethical issues in ethnographic written texts: confidentiality is typically promised to participants at the outset of the research relationship. However, it is mostly in the final ethnographic text that such promises are put to the test. Extracts from conversations, although anonymized in the text, still belong to the participants who voiced these views, but rarely are we aware of them having the power to exercise editorial authority. So, ethnographers are frequently confronted with the need to establish limits as to what to reveal in their texts, and under what conditions. To put it simply, an ethical confrontation emerges between producing knowledge and upholding ethically defensible values. Also, in the specific case of the ethnographies of crime and deviance, how can we, for instance, describe crimes either without breaking confidentiality or becoming accomplices? Going on the journey of the life histories shared by criminals inevitably involves researchers as their co-associates in some way. Surely, Scheper-Hughes' (2004) suggestion that we do away with anonymity 
altogether, while potentially interesting in the sense that it would lead to more judicious texts, is never easy to apply.

Fine addresses this moral dilemma, taking care in stressing its positive side:

"Transformation is about hiding, about magic, about change. This is the task we face and is the reality that we must embrace. We ethnographers cannot help but lie through a tacit concealment of things shared, but in this mendacity, we reveal often truths that escape those who are not so bold" (Fine 1993: 290).

It is highly likely that many ethnographers of crime and deviance clearly recall the seminars in which they first presented their data, and based on the audiences' reactions realized what they have to leave out of publications, and what needs to be framed in very careful fashion if they are to succeed peer review.

In our polemically inclined section we hope we have been clear in pointing, even if very briefly, to some of the most fundamental ethnographic dilemmas which may be suppressed and clandestinely repressed by the tenets of scholarly conservativism. We also hope we have made their complexities, subtleties and dynamism apparent, and public. It is with this in mind that we move to discussing the limits of anticipatory regulatory regimes and to suggesting other ways of considering ethical issues in ethnography, with a focus on the role that reflexivity can play in that process of ethical dissemination and problematizing.

\section{TOWARDS A RESPONSIBLE HUMANISTIC ETHICS FOR RESEARCH}

Institutional anticipatory regulatory regimes are the "elaborate, bureaucratized, systems of ethical review" that operate with special vigour in the Anglophone world, but have now spread globally (Murphy and Dingwall 2007: 2224). Writing from a peripheral Latin European country (Portugal) and a small Celtic quasi-nation state (Scotland), we sometimes can't help feeling that they are a bit like any other imported, globally fashionable commodities; that is, they are consumed to demonstrate ability at "playing the game" as Bourdieu terms academic life. The game in question is not about ethics nor is it particularly ethical. That it presents as ethical is ironic. As a dominant form, this game of careful subterfuge is certainly about controlling the autonomy of individual thinkers and steering research cultures away from tinkering with the values capitalism endorses.

Coercive regimes can take many forms, physical, mental or combinations. Like royal families they are immensely flexible to historical conditions, it is their way of guaranteeing continual longevity. Ethical audit regimes emerged in the biomedical field following the Nuremberg trials: Nazis' science was 
fortunately exposed and its gruesome experimentations with human subjects recognized as barbaric. Not to the same depth or extent of Hitler's assault on humanity is biomedical research continual covert malpractices conducted in the name of progressing science in the contemporary world (Murphy and Dingwall 2007; Bengry-Howell and Griffin 2012). Clearly, the consolidation of such regimes has benefited from the intensified globalization of the risk society (Beck 1997), which obviously does not refer to a society that is more dangerous than ever - in many ways, quite the contrary (Pinker 2011) - but rather to a society obsessed with risk management and control. This type of social organization has had its consequences in the ethical realm, namely by shifting ethical questions from "the 'moral self' to a system of institutionalized impersonal moral codes and practices" (Ferdinand et al. 2007: 534). It is concealment through the exercise of the juridical-like authority of institutions. Being remote, authority becomes difficult to challenge or to require it to be subject to demand for justification by affected parties.

This makes the "standard ethics review process more akin to a risk management exercise at the behest of the host institution or funding body. It is not thorough and sensitive review that even remotely addresses the ethical needs of qualitative researchers" (Tolich and Fitzgerald 2006: 72; see also Connolly 2007). It could be argued that, given that most ethnographic research is conducted by those working in government-supported institutions, the ethical process is in fact a form of censorship - or at the very least primarily about protecting conformity to legal safeguards to research institutions. The safety and well-being of the research subjects in the real world is not its true focus; sometimes non-funded research may be exempt from ethics review processes (Katz 2006). It should be noted here that the dangers posed to humanity and the individual by biomedical, clinical research are paradigmatically different from those posed by ethnographies in terms of their nature, extent and possibility of anticipation and communication (Murphy and Dingwall 2007). Yet, the focus of anticipatory regulatory regimes on ensuring informed consent and prevention of harm to research subjects does have the benefit of compelling ethnographers to reflect on at least those two elements. Also, to be sure, there are preparatory, anticipatory steps and mechanisms that may contribute to conducting ethically sound research, such as the establishment of professional codes of conduct, the identification and discussion of possible ethical issues before they arise in the field, and even the effort put into procedural ethics - that is, in the search for approval by ethics committees (Guillemin and Gillam 2004) - notwithstanding the fact that it may encompass an element of deception as inductive research models are disguised within a deductive frame (Tolich and Fitzgerald 2006).

Nevertheless, we would argue that there is an unsurpassable gap between anticipatory regulatory regimes and ethical decision-making in ethnography 
conducted in the field rather than through historical desk research. That is, anticipatory regulatory regimes are unfit for supporting or enabling ethnography (Katz 2006; Tolich and Fitzgerald 2006; Allbutt and Masters 2010). This is apparent in at least three areas: the nature of ethics, the time of ethical decision making, and the ethical subject. We will now go through the three of them, underscoring a reflexive understanding of ethics and ethical decision making in each case before we offer a conclusion to our discursive paper.

\section{The nature of ethics}

To begin with, while meta-ethical concerns are part and parcel of the ethnographic approach, they seem less relevant in anticipatory regulatory regimes. That is, while ethnographers, we would dare say by definition, are particularly interested in analyzing the status, meaning and nature of moral claims - including their own -, ethics committees, given their mandate, are mostly concerned with applying a given normative ethical framework reflecting a dominant bureaucracy and system of audit culture management (or even censorship). This is a fundamental gulf between the markedly reflexive approach of ethnographers and the essentially prescriptive deductive approach of (common) ethics committees in anticipatory regulatory regimes and, indeed, of lay persons (Goodwin and Darley 2008). Thus, while some are trying to revise, continuously adjust and complexify ethical decision making, others are trying to (over)simplify it, seeking to establish by decree a sort of disembodied zombie like equivocal ethical universalism.

To be sure, this discrepancy derives from the scientific and sociological contexts of the origin of both approaches which face capitalism through conflicting discourses. While "anticipatory regulatory regimes are based on assumptions derived from clinical trials or biomedical experimentation, with prior specification of hypotheses, design, instruments and implementation in protocols that are finalized before the study begins" (Murphy and Dingwall 2007: 2225), ethnographic thinking about ethics stems from the radically different method of deep immersion in the field and the responsiveness to serendipity; as argued by Roriz and Padez (2017: 76), these are two incommensurable models. The latter is necessarily unpredictable, but it is a basic characteristic of the conduct of ethnographic studies where induction is paramount. Also, the distinction mentioned relates to the different status of context in the ethnographic and the anticipatory regulatory approaches. Indeed, ethnography seeks to be of assistance in providing understanding of what ethics is about, how it is socially organized and context-bound; in short, "why are these issues defined as ethical concerns by these people in these times and these places?" (Haimes 2002: 113). Ethnographers of crime and deviance, given the tensional, often radically contrasting settings in which they conduct their studies, are almost inevitably pushed to embracing personally challenging meta-ethical questions 
(see, for instance, recent research by Castellano 2007; Ferdinand et al. 2007; Diphoorn 2013; Haimes 2002). Elsewhere, Neves and Malafaia (2016: 52-53) highlight how impression management aimed at naturalizing the ethnographer's presence in the field involves a degree of relational manipulation and parasitical predation of the expectations of the research subjects.

\section{The timing of ethical decision making}

Here, too, reflexivity makes a difference, as it encourages ongoing decision-making rather than the a priori, once and for all decisions typical of anticipatory regulatory regimes. Informed consent as configured in the biomedical model, for example, verges on absurdity when applied to ethnographic studies, most certainly so in ethnographies of crime and deviance (MacRae and Vidal 2006; Deuchar 2016). Indeed, to show up in the field with a piece of paper requiring subjects to sign it at the outset of their participation is odd, to say the least. This is particularly the case when research participants are seen as "hard to reach". For example, as authors all three of us have had the experience of having to issue written consent forms to young offenders who are naturally distrustful - sometimes this has increased their suspicion and even led to a reluctance to engage with us at all (see, for instance, Deuchar 2009, 2016). There are also other reasons why this process is strange and unnatural. First, it gives birth to a prematurely contractualised relationship between researcher and research subject. It is premature because, given the emergent, progressive nature of ethnographic research focus and design, there is really not that much binding them at the outset of the research process. Second, it assumes an all or nothing, black or white understanding of participation in research. In reality things usually not only go through several shades of grey - just like moving through the continuum of overtness and covertness in researchers' roles but also forwards and backwards. In any case, to be consistent, that kind of informed consent would probably need to go through at least two stages: the beginning and the end - that is, the publication - of the research (Tolich and Fitzgerald 2006), namely in order to account for the difference between internal and external confidentiality (Tolich 2004).

Third, it is inapplicable to research that is based on observation of public behaviour, as it is obviously impossible to apply informed consent forms to each and every person going through a public setting. One example from our experiences in the field illustrates this well. As a policing scholar, the third author has regularly engaged in participant observation of deployments in busy public thoroughfares in both Scotland and the USA. In addition to observing the behaviour of primary research participants (police officers), in the heat of the police operations he has also often come into contact with secondary groups of participants (local community residents and passers-by) who were initially uninformed about his researcher identity, but later made 
aware of this. Further, in some cases the nature of the police interaction has been such that any attempt to intervene and seek formal consent from local participants would have been both obtrusive and inappropriate. Thus, these tertiary participants have remained unaware of the researcher's identity, but were observed and ultimately became part of his field notes (Deuchar 2013, 2016).

In sum, as configured in the biomedical model, informed consent is a discrete event rather than a negotiated process (Bengry-Howell and Griffin 2012), and therefore it lies on the antipodes of ethnographic practice. Wanting to apply it ipsis verbis to ethnography can only lead to smothering ethnographic practice, either by preventing it from being carried out or by leading to mitigated forms of ethnography, based not so much on prolonged participant observation but instead on more controllable, formalized, research strategies such as interviews and focus groups. Such strategies are more easily adaptable to checklists of rights and wrongs than ethnography, where data collection is iterative (Murphy and Dingwall 2007), unbounded, and the research process usually far from linear (Tolich and Fitzgerald 2006). We should add that in our interactions with colleagues from Anglophone countries we have actually come to realize that some of our research would never have been approved by their ethics committees - even if, at the end, and to the best of our knowledge, no real harm emerged for anyone involved. Yet again, from a reflexive stance, "being ethical is not something that can be measured against a checklist of "rights and wrongs'" (Ferdinand et al. 2007: 520). This simple, powerful statement summarizes many of the critiques that can be addressed against anticipatory regulatory regimes.

\section{THE ETHICAL SUBJECT}

Whereas biomedical, clinical research is a collective endeavour, ethnographies are, typically, the result of mostly individual efforts. So, to begin with, there is an important difference in the degree of responsibility sharing in both types of research. To be sure, this does not constitute by itself sufficient motive to exempt ethnographies from external ethical appreciation. However, together with the aforementioned differences in the research processes, it may make ethnographers less sympathetic to such appreciations, particularly when conducted $a$ priori by people who tend to have little knowledge of ethnography, or even qualitative social research for that matter (Tolich and Fitzgerald 2006). Of course, it is not only a question of different research models. It is also a matter of power. Indeed, the reverse situation is imaginable: one in which the ethnographic, or the qualitative, approach would be the "universal" model for evaluating research ethics. It wouldn't make sense either. We did not bring this up because it makes sense, but simply to highlight the power differential 
between both research traditions. This power differential both constitutes and is constituted by, amongst other things, the government of subjectivity, that is, the subtle, indirect regulation of individuals' values and behaviour to bring them in tune with socially and institutionally prized goals (Rose 1990). In the contemporary risk society, linear, anticipatory, deductive approaches are valued because they (appear to) provide more control over the future course of events. Risk management is also apparently made easier by removing important decisions from the hands of individuals and placing them in the hands of bureaucrats. Those familiar with recent transformations in justice systems can certainly find parallel here with the rise of the culture of control (Garland 2001) and actuarial justice (Feeley and Simon 1992). The trouble with this legalistic, managerial approach to ethics is that it smothers the self-constitution of the ethical subject (Foucault 1990), and substitutes a remote collective for the individual in the field. In the process, of course, reflexivity takes a major blow.

There are, then, very concrete dangers for ethnography as a result of the enforcement of anticipatory regulatory regimes: the development of mitigated forms of ethnography, the obstruction of ethnographies in sensitive contexts, and the externalization of the researcher's ethical responsibility, which may lead to his or her own de-responsibilisation.

\section{CONCLUSION}

Our paper has sought to contribute to discussions of reflexivity in criminological research by focusing on the issue of ethics. Specifically, it has contrasted the currently dominating anticipatory regulatory regimes, home of procedural ethics, with the intrinsically reflexive and morally problematical nature of ethnographic ethical decision making.

It has attempted to cover a wide spectrum of multi-disciplinary literature both in terms of time of publication and canonical status - from Malinowski in 1922 to studies just published in 2016 - and focus - from classic ethnographies of crime and deviance to methodological texts, with special emphasis on ethical debates. This has served to highlight both the longevity and unresolved nature of reflexive ethical concerns in ethnography, as well as foregrounding the current relevance of the paper's specific topic.

To conclude, a few points that sum up the core ideas in the paper regarding ethnographic ethical reflexivity, hoping that they can be of use for existing and future ethnographers:

- Reclaim your ethical power, by joining, engaging in productive negotiations with, or, if necessary, confronting ethical review boards.

- Take on full responsibility for the research process and the research product, even if shielded by procedural ethics and professional codes of 
conduct, or by claims to giving voice to the disempowered or creating collective narratives.

- Provide the fullest possible account of ethical standpoints, dilemmas and decisions, bearing in mind Scheper-Hughes' call for a "highly disciplined subjectivity" (Scheper-Hughes 2000, cited in Stein 2010: 565).

- Reframe and enlarge the notions and the possibilities of what is ethical. Argue that ethics should not be simplified, meaning reduced, but rather complexified, made context-bound.

- Accept that there is a darker side to ethnography, which involves imbalances in reciprocity, a degree of predatory manipulation of relationships and chameleonic opportunism on the part of the ethnographer.

- Be reflexive in order to find a way out of the tension between realism and relativism, not by "pursuing a new form of absolute knowledge, but [by] exercising a specific form of epistemological vigilance" (Bourdieu 2004: 89).

The beauty of ethnography comes from its humanity. The humanity of the ethnography of crime and deviance should be apparent in the fact that the ethnographer, like those he/she studies, is not immaculate. Finally, and by way of caveat we admit that the thinking presented in this paper, like much of the literature on research ethics, begs fundamental philosophical questions about morality. Research ethics cannot avoid being parasitic upon ancient philosophical controversies concerning the nature of morality, including questions of right and wrong handed down to us from Plato and Aristotle.

\section{REFERENCES}

ADLER, Patricia A., and Peter ADLER, 1987, "The past and the future of ethnography", Journal of Contemporary Ethnography, 16: 4-24.

ADLER, Patricia A., Peter ADLER, and E. Burke ROCHFORD, 1986, "The politics of participation in field research", Urban Life, 14: 363-376.

ALLBUTT, Helen, and H. MASTERS, 2010, "Ethnography and the ethics of undertaking research in different mental healthcare settings", Journal of Psychiatric and Mental Health Nursing, 17: 210-215.

ANDERSTAAY, Steven L., 2005, "One hundred dollars and a dead man: ethical decision making in ethnographic fieldwork", Journal of Contemporary Ethnography, 34: 37 1-409.

ATKINSON, Paul, Amanda COFFEY, and Sara DELAMONT, 1999, "Ethnography: post, past, and present", Journal of Contemporary Ethnography, 28: 460-471. 
BECK, Ulrich, 1997, Risk Society: Towards a New Modernity. London, Sage.

BENGRY-HOWELL, Andrew, and Christine GRIFFIN, 2012, "Negotiating access with 'hard to reach' young people: establishing common ground or a process of methodological grooming?", International Journal of Social Research Methodology, 15: 403-416.

BERG, Lawrence D., Eduard H. HUIJBENS, and Henrik Gutzon LARSEN, 2016, "Producing anxiety in the neoliberal university", The Canadian Geographer/Le Géographe Canadien, 60: 168-180.

BIERSACK, Aletta, 1989, "Local knowledge, local history: Geertz and beyond”, in L. Hunt (ed.), The New Cultural History. Berkeley and Los Angeles, CA, University of California Press, 72-97.

BOURDIEU, Pierre, 2004, Science of Science and Reflexivity. Chicago, The University of Chicago Press.

BOURGOIS, Philippe, 1996, In Search of Respect: Selling Crack in El Barrio. Cambridge, Cambridge University Press.

BRONFENBRENNER, Urie, 1952, "Principles of professional ethics: Cornell studies in social growth", American Psychologist, 7: 452-455.

BRUNT, Lodewijk, 1999, “Thinking about ethnography”, Journal of Contemporary Ethnography, 28: 500-509.

BURGESS, Robert G., 1997, A Pesquisa de Terreno: Uma Introdução. Oeiras, Celta Editora.

CASTELLANO, Ursula, 2007, "Becoming a nonexpert and other strategies for managing fieldwork dilemmas in the criminal justice system", Journal of Contemporary Ethnography, 36 (6): 704-730.

CONNOLLY, Kate, 2007, "Ethics review for qualitative inquiry", Qualitative Inquiry, 13: $1031-1047$.

COSTA, António Firmino da, 1986, "A pesquisa de terreno em sociologia", in Augusto Santos Silva and José Madureira Pinto (eds.), Metodologia das Ciências Sociais. Porto, Afrontamento, 129-149.

DEUCHAR, Ross, 2009, Gangs, Marginalised Youth and Social Capital. Stoke on Trent, Trentham.

DeUCHAR, Ross, 2013, Policing Youth Violence: Transatlantic Connections. London, IOE Press.

DEUCHAR, Ross, 2016, "Dilemmas, deception and ethical decision-making: insights from a transatlantic ethnographer", in Kalwant Bhopal and Ross Deuchar (eds.), Researching Marginalized Groups. New York, Routledge, 62-74.

DIPHOORN, Tessa, 2013, "The emotionality of participation: various modes of participation in ethnographic fieldwork on private policing in Durban, South Africa”, Journal of Contemporary Ethnography, 42: 201-225.

EMERSON, Robert M., Rachel I. FRETZ, and Linda L. SHAW, 1995, Writing Ethnographic Fieldnotes. Chicago, The University of Chicago Press.

FEELEY, Malcolm M., and Jonathan SIMON, 1992, “The new penology: notes on the emerging strategy of corrections and its implications", Criminology, 30: 449-474.

FERDINAND, Jason, et al., 2007, "A different kind of ethics", Ethnography, 8: 519-543.

FERNANDES, Luís, 2002, O Sítio das Drogas. Lisbon, Editorial Notícias.

FINE, Gary Alan, 1993, “Ten lies of ethnography: moral dilemmas of field research”, Journal of Contemporary Ethnography, 22: 267-294.

FOUCAUlT, Michel, 1990, Tecnologías del Yo. Barcelona, Paidós. 
GARLAND, David, 2001, The Culture of Control: Crime and Social Order in Contemporary Society. Chicago, The University of Chicago Press.

GEERTZ, Clifford, 1993, The Interpretation of Cultures: Selected Essays. London, Fontana Press. GOFFMAN, Erving, 1969, The Presentation of Self in Everyday Life. London, Penguin Books.

GOODWIN, Geoffrey P., and John M. DARLEY, 2008, "The psychology of meta-ethics: exploring objectivism", Cognition, 106: 1339-1366.

GUILlEMIN, Marilys, and Lynn GILlAM, 2004, "Ethics, reflexivity, and 'ethically important' moments in research”, Qualitative Inquiry, 10: 261-280.

HAIMES, Erica, 2002, "What can the social sciences contribute to the study of ethics? Theoretical, empirical and substantive considerations”, Bioethics, 16: 90-113.

HAMMERSLeY, Martin, and Paul ATKINSON, 2007, Ethnography: Principles in Practice. London, Routledge.

HAMMERSLEY, Martin, and Anna TRAIANOU, 2014, "Foucault and research ethics: on the autonomy of the researcher", Qualitative Inquiry, 20: 227-238.

IRWIN, Katherine, 2006, "Into the dark heart of ethnography: the lived ethics and inequality of intimate field relationships", Qualitative Sociology, 29: 155-175.

JENKS, Chris, and Tiago NEVES, 2000, "A walk on the wild side: urban ethnography meets the flâneur", Cultural Values, 4: 1-17.

KATZ, Jack, 2006, "Ethical escape routes for underground ethnographers", American Ethnologist, 33: 449-506.

KEITH, Michael, 1992, "Angry writing: (re)presenting the unethical world of the ethnographer", Society and Space, 10: 551-558.

LEWIS, Sue J., and Andrew J. RUSSELL, 2011 , "Being embedded: a way forward for ethnographic research", Ethnography, 12: 398-416.

LOCKE, Steven, Carlos J. OVANDO, and Carmen MONTECINOS, 2016, "Institutional power and the IRB: saving souls or silencing the other in international field work", in K. Bhopal and R. Deuchar (eds.), Researhing Marginalized Groups. New York, Routledge, 225-238.

LUMSDEN, Karen, 2012, “'You are what you research': research partisanship and the sociology of the "underdog' ", Qualitative Research, 13: 3-18.

MacRAE, Edward, and Sergio Souza VIDAL, 2006, "A Resolução 196/96 e a imposição do modelo biomédico na pesquisa social: dilemas éticos e metodológicos do antropólogo pesquisando o uso de substâncias psicoativas", Revista de Antropologia, 49: 645-666.

MALINOWSKI, Bronislaw, 1984 [1922], Argonauts of The Western Pacific. Long Grove, IL, Waveland Press.

MURPHY, Elizabeth, and Robert DINGWALL, 2007, "Informed consent, anticipatory regulation and ethnographic practice”, Social Science \& Medicine, 65: 2223-2234.

NEVES, Tiago, 2008, Entre Educativo e Penitenciário: Etnografia de Um Centro de Internamento de Menores Delinquentes. Porto: Afrontamento.

NEVES, Tiago, and Carla MALAFAIA, 2016, “'You study people... that's ugly!': The implications of ethnographic deceptions for the ethnographer's ethics”, in Kalwant Bhopal and Ross Deuchar (eds.), Researching Marginalized Groups. New York, Routledge, 50-61.

PINKER, Steven, 2011 , The Better Angels of Our Nature: A History of Violence and Humanity. London, Penguin.

ROBERTS, Brian, 1975, "Naturalistic research into subcultures and deviance", in T. Jefferson (ed.), Resistance through Rituals: Youth Subcultures in Post-War Britain. Birmingham, Centre for Contemporary Cultural Studies, 243-252. 
RORIZ, Marta, and PADEZ, Cristina, 2017, "A regulação ética da investigação e os desafios postos às práticas etnográficas", Etnográfica, 21 (1): 75-95, available at < https://journals.openedition.org/etnografica/4820 > (last access in June 2018).

ROSE, Nikolas, 1990, Governing the Soul: The Shaping of the Private Self. London, Routledge.

SCHEPER-HUGHES, Nancy, 2000, "Ire in Ireland", Ethnography, 1: 117-140.

SCHEPER-HUGHES, Nancy, 2004, "Parts unknown: undercover ethnography of the organs-trafficking underworld”, Ethnography, 5: 29-73.

STEIN, Arlene, 2010, "Sex, truths, and audiotape: anonymity and the ethics of exposure in public ethnography”, Journal of Contemporary Ethnography, 39: 554-568.

TOLICH, Martin, 2004, "Internal confidentiality: when confidentiality assurances fail relational informants”, Qualitative Sociology, 27: 101-106.

TOLICH, Martin, and Maureen H. FITZGERALD, 2006, "If ethics committees were designed for ethnography", Journal of Empirical Research on Human Research Ethics, 1: 71-78.

VAN DEVENTER, J. Phil, 2009, "Ethical considerations during human centred overt and covert research", Quality \& Quantity: International Journal of Methodology, 43: 45-57.

WALSH, David, 1998, "Doing ethnography”, in C. Seale (ed.), Researching Society and Culture. London, Sage, 225-239.

WEBER, Max, 1949, The Methodology of the Social Sciences. Glencoe, IL, The Free Pres of Glencoe.

WEPPNER, Robert S., 1977, “Street ethnography”, in R.S. Weppner (ed.), Street Ethnography: Selected Studies of Crime and Drug Use in Natural Settings. Beverly Hills and London, Sage, $21-51$.

WHYTE, William Foote, 1993 [1943], Street Corner Society: The Social Structure of an Italian Slum. Chicago, The University of Chicago Press. 